\title{
SELECTION OF SUSTAINABLE RURAL AGRICULTURE PROJECTS IN SOUTH AFRICA: CASE STUDIES IN THE LANDCARE PROGRAMME
}

\author{
Alan C Brent, Jacques Mulder \\ Chair of Life Cycle Engineering \\ Department of Engineering and Technology Management \\ University of Pretoria, South Africa
}

\begin{abstract}
The LandCare programme of the South African national government aims to address problems associated with the degradation of natural resources by facilitating rural agricultural projects that are sustainable over their entire lifecycles. This paper summarises the development of a new set of project selection criteria for the evaluation of project proposals in order to compile an effective LandCare programme portfolio. The new project selection criteria were developed through a review of current literature, existing criteria applied in previously selected projects and interviews with key stakeholders during project site visits. These site visits were also used to determine criterion weights, which were calculated using the Analytical Hierarchy Process (AHP), a known decision-analysis technique. The established set of criteria was applied to three case studies in South Africa, through which an evaluation procedure is further demonstrated. Thereby a successful project portfolio can be ensured that is dedicated to all three components of sustainable development in rural areas.
\end{abstract}

\section{Introduction}

The general scarcity of natural and agricultural resources in South Africa necessitates the implementation of sustainable agricultural management practices. In order to achieve wider participation in agricultural support programmes and proactively involve all community members in the management of natural resources, the national LandCare programme was initiated in 1997 [1]. The overall objective of this programme is to optimise productivity and ensure sustainable use of natural resources; thereby achieving greater food security, job creation and a better quality of life for all [1].

\section{Objectives of the study}

The current project success rate within the LandCare programme is testimony to poorly planned projects, with few projects completed on time, within the budget and of acceptable quality. Only a small number of projects are taken further after project closure, placing a big question mark on the sustainability of the LandCare programme. The study, summarised in this paper, was subsequently undertaken to develop new selection criteria as well as an appropriate evaluation procedure in order to filter project proposals effectively and ensure sustainable project lifecycle performances, and to compile the best possible LandCare programme portfolio. The use of appropriate project selection criteria aims to identify proper projects that will be funded and implemented. These criteria also guide project planners as to what is required in a project plan. Although this is by no means a guarantee that projects will be successfully implemented, good project plans significantly improve the chances of project success. 


\section{Proposed criteria and procedure for LandCare project evaluation}

\section{Approach to compile a set of appropriate criteria}

The set of effective criteria for the LandCare programme was compiled using a qualitative research approach. The research process was comprised of a critical analysis of existing criteria and indicators, and a number of one-on-one interviews. As the LandCare programme requires a holistic perspective of proposed projects, all elements of sustainable development had to be considered. The critical analysis was performed bearing ongoing LandCare projects in mind. The criteria and indicators included in the analysis were [3]: the current LandCare criteria [2]; proposed Clean Development Mechanisms (CDM) project evaluation criteria [4]; the World Bank's indicators of land quality and sustainable land management [5]; criteria for assessing the sustainability performances of industries [6]; and proposed methodologies to assess the sustainability of land use management practices in rural areas [7]. To complement the information obtained from the critical analysis, interviews were conducted with nine provincial LandCare coordinators. These individuals are responsible for the coordination of LandCare efforts in each province, which include the implementation of projects, facilitation with communities and support to the implemented projects. The interviews established the factors that are perceived by stakeholders actively involved in the LandCare programme as critical for project success. The criteria are grouped into: social sustainability; economic sustainability; environmental sustainability; and technical feasibility. The purpose of grouping the selection criteria in this manner is to assist the team, which is responsible to evaluate project proposals, in determining the potential impacts that a project will have in a structured and logical manner. The hierarchical structured selection criteria and indicators, listed in Table 1 [3], incorporate all of the important or applicable aspects that are addressed by the published approaches. Further details on the classification that is used for each indicator are provided in elsewhere [3,8]. The compiled criteria also support the vision, aims and goals of the LandCare programme [1].

\section{Proposed procedure to evaluate LandCare projects}

A scaling factor $(-1$ to +1$)$ is assigned to each criterion, based on an introduced 'class' change in a community after project implementation. These 'classes' have been defined in detail elsewhere $[3,8]$. Community members and the PDA should jointly determine the current baseline class, regarding the state of the criterion in the community. The community's needs regarding the criterion class are then identified through a process of participation. Thereafter, the project's impact on the criterion is determined, i.e. how the project would affect the class of the criterion. A single class difference indicates a moderate change, while a class difference of two or more indicates a significant change. The conformance of the class change to the community needs is assessed on a similar scale. By following this process both the project performance and conformity to community needs are evaluated. Some of these indicators require a subjective evaluation by project management expertise, specifically for determining effects and comparing these to a baseline. Other criteria such as representation, community participation, leadership and community contribution do not require baseline information as performances are directly measured. Technical 
sustainability indicators are either a go or a no-go decision for the entire project with respect to its projected sustainability. This component is subsequently not included in the sustainability evaluation procedure. These indicators are subjective, but the evaluation and project selection process is consistent as only one committee evaluates all the project proposals. The evaluation committee may choose not to fund a project if the overall project performance and conformance to community needs are not deemed adequate. For such an overall evaluation weighting values for the different criteria and indicators are required.

\section{The establishment of weighting values of the selection criteria and indicators}

\section{Methodology to establish the weighting values}

Weighting factors for the selection criteria were primarily determined through the Analytical Hierarchy Process (AHP), which is a known multi-attribute weighting method for decision support [9]. The AHP has been used before for the purposes of weighing criteria and indicators for sustainable development in certain industry sectors.

\section{Choice of panel}

LandCare coordinators and representatives from all nine provinces of South Africa, as well as members of the LandCare secretariat attended the workshop where the selection criteria were discussed. A total of 20 officials, all with extensive experience in the planning and implementation of LandCare projects, attended the workshop where each criterion was weighed in a hierarchical manner to establish its perceived importance. The weighting values are documented elsewhere [3, 8].

\section{Case studies to demonstrate the evaluation procedure with the proposed criteria}

Three case studies in two of the South African provinces were selected for evaluation [3, 8]:

1. A water harvesting project (Koringkoppies) [2];

2. A cattle project (Thuo-Boswa) [10]; and

3. A crop production project (Lwatshatsimu) [11].

Although these cases differ significantly in their focus, they are representative of the majority of LandCare projects. The three projects were chosen based on the sufficient and relevant information that were captured in the project plans of each project, thereby allowing for proper evaluation. Since all three case study projects have been completed, it was also possible to verify the results of the research on site.

\section{Case study results}

The project performances, according to social, economic and environmental sustainability for the case studies, are summarised in Table 2 . The table summarises the detailed evaluations that have been described elsewhere $[3,8]$. 


\section{Conclusions}

A successful LandCare project portfolio would consist of projects that are dedicated to all three components of sustainable development in rural areas. Sound selection criteria will ensure the correct assembly of such a project portfolio. This study has illustrated that the proposed project selection criteria for LandCare projects allow the LandCare programme to make a meaningful contribution to sustainable development. The research findings and their application to the case studies show that the developed selection criteria could be used to evaluate project proposals effectively. The incorporation of both overall project lifecycle impact as well as conformity to community needs in the procedure facilitates more informed decisions.

\section{References}

[1] NDA (South African National Department of Agriculture). (2005, June 6). LandCare South Africa. [Online]. Available: http://www.nda.agric.za/docs/Landcarepage/landcare.htm.

[2] NDA (South African National Department of Agriculture), Koringkoppies LandCare Project - A good LandCare practice model. LandCare project report, Department of Agriculture, Pretoria, South Africa, 2002.

[3] J. Mulder, Project selection criteria for LandCare projects. Masters dissertion, Department of Engineering and Technology Management, University of Pretoria, South Africa, 2003.

[4] A. C. Brent, R. Heuberger, and D. Manzini, "Evaluating projects that are potentially eligible for Clean Development Mechanism (CDM) funding in the South African context: A case study to establish weighting values for sustainable development criteria", Environmental and Development Economics, in press, 2005.

[5] J. Dumanski, S. Gameda, and C. Pieri. (2005, June 6). Indicators of land quality and sustainable land management. The World Bank, Sustainable Rural Development Information System (SRDIS). [Online]. Available: http://srdis.ciesin.org/, 1998.

[6] C. Labuschagne, A.C. Brent, and R.P.G. van Erck, "Assessing the Sustainability Performances of Industries", Journal of Cleaner Production, Vol. 13, No. 4, pp. 373-385, 2005.

[7] A. Bosshard, "A methodology and terminology of sustainability assessment and its perspectives for rural planning", Agriculture, Ecosystems and Environment, Vol. 77, pp. 29-41, 2000.

[8] J. Mulder, and A.C. Brent, "Selection of Sustainable Rural Agriculture Projects in South Africa: Case Studies in the LandCare Programme", Journal of Sustainable Agriculture, in press, 2005.

[9] T.L. Saaty, The Analytic Hierarchy Process. McCraw-Hill, New York, 1980.

[10] NDA (South African National Department of Agriculture), Thuo-Boswa Cattle Project - A good LandCare practice model. LandCare project report, Department of Agriculture, Pretoria, South Africa, 2002.

[11] NDA (South African National Department of Agriculture), Lwatshatsimu LandCare Project - A good LandCare practice model. LandCare project report, Department of Agriculture, Pretoria, South Africa, 2002. 